\title{
Narrative Readings of the Religious Authorities in John: A Response to Urban C. von Wahlde
}

\author{
CHRISTOPHER W. SKINNER \\ Loyola University Chicago \\ Chicago, IL 60660
}

Abstract: The third fascicle of New Testament Studies in 2017 contained an article by Urban C. von Wahlde in which he critiqued contemporary narrative readings of the religious authorities in the Fourth Gospel. In this article, I respond to some of his claims by (1) pointing out specific concerns he has overlooked, and (2) providing a counterpoint to some of his broad claims about contemporary narrative-critical readings of the Fourth Gospel.

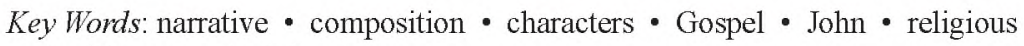
authorities - methodology

IT IS INEVITABLE that different methodological approaches to texts produce different readings. This issue was highlighted in a recent essay in New Testament Studies by Urban C. von Wahlde entitled "Narrative Criticism of the Religious Authorities as a Group Character in the Gospel of John: Some Problems." The article offered a critique of current research on narrative-critical character analysis of "the Jews" and other religious authorities in the Fourth Gospel. Understanding

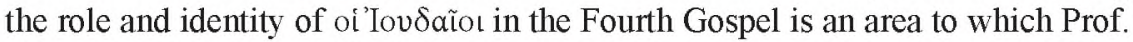

I presented a previous version of this article at the Midwest Regional Meeting of the Society of Biblical Literature in South Bend, Indiana, in February 2019. I would like to thank those who interacted with the paper as well as the two anonymous reviewers who offered helpful suggestions that improved this article.

${ }^{1}$ Urban C. von Wahlde, "Narrative Criticism of the Religious Authorities as a Group Character in the Gospel of John: Some Problems," NTS 63 (2017) 222-45 (page references to this article will be given in parentheses in the text). 
von Wahlde has devoted a significant amount of energy over the years, and his contributions on the subject are well known within Johannine studies. ${ }^{2}$ However, several elements of his argument from this most recent article invite further consideration. Von Wahlde's critique displays a dismissive attitude toward narrative criticism, as well as a misunderstanding of how narrative-critical approaches function in current scholarship. The present article represents a response to Prof. von Wahlde's "problems" accompanied by a plea for greater clarity when it comes to the evaluation of the well-established conventions of narrative criticism in NT studies.

It will prove helpful to engage briefly here with von Wahlde's previous work on the Johannine literature as a point of entry into our examination of his critique of narrative-critical readings. Known for his "composition-critical" approach, von Wahlde has written a great deal about compositional disunity in the Johannine literature. ${ }^{3}$ A foundational assumption for von Wahlde's entire Johannine project is that there are three distinct versions of the Fourth Gospel, each with its own community concerns, christological emphases, and redactional idiosyncrasies. In his research, he points out numerous aporiae and redactional techniques, which he further argues are clearly discernible through the lens of his methodological approach. ${ }^{4}$ It is fair to say that a great deal of von Wahlde's work on the Johannine literature is focused on identifying disunity through locating literary seams in the Gospel. The practical result of this sort of investigation is an overarching emphasis on sources, compositional techniques, and the ways in which the different versions he posits are discerned through a careful reading of the final text. As we examine von Wahlde's analysis of narrative-critical readings of the Jews in the Fourth Gospel, it will be important to keep these related foci in mind.

${ }^{2}$ See, e.g., the following works by von Wahlde: "The Terms for Religious Authorities in the Fourth Gospel: A Key to Literary Strata?," JBL 98 (1979) 231-53; "The Johannine 'Jews': A Critical Survey," NTS 28 (1982) 33-60; "Literary Structure and Theological Argument in Three Discourses with the Jews in the Fourth Gospel," JBL 103 (1984) 575-84; "The Relationships between Pharisees and Chief Priests: Some Observations on the Texts in Matthew, John, and Josephus," NTS 42 (1996) 506-22; "“The Jews' in John's Gospel: Fifteen Years of Research (1983-1998)," ETL 76 (2000) $30-55$. One could reasonably argue that this area of research has been foundational to von Wahlde's entire Johannine project.

${ }^{3}$ See esp. Urban C. von Wahlde, The Gospel and Letters of John (3 vols.; ECC; Grand Rapids: Eerdmans, 2010).

${ }^{4}$ See, e.g., Urban C. von Wahlde, "A Redactional Technique in the Fourth Gospel," CBQ 38 (1976) 520-33; idem, "Wiederaufnahme as a Marker of Redaction in Jn 6:51-58," Bib 64 (1983) 542-49; idem, "Community in Conflict: The History and Social Context of the Johannine Community," Int 49 (1995) 379-89. 


\section{Von Wahlde's Critique of Recent Narrative-Critical Readings}

\section{Von Wahlde on Narrative Criticism}

Before I consider von Wahlde's specific critique, I must note that he begins his examination of narrative-critical readings of the religious authorities in John with a fairly sweeping dismissal of contemporary narrative-critical studies as a whole. He writes:

The use of narrative criticism in the study of the Gospel of John has been popular for over thirty years. One of the attractions of the method is that it provides a means that is methodologically grounded for approaching the Gospel of John in its present form - without the need to try to explain all of the peculiar features of the Gospel. I do not say that this was the rationale of the earliest proponents of the method. But any method that frees the critic from the complexities and perplexities of the Gospel as it stands does have an obvious appeal to it. This certainly has not hurt the possibilities of its more general acceptance. (222; emphasis added)

We must begin by recognizing this paragraph as a caricature. Von Wahlde first describes the method as "popular," after which he twice suggests that scholars choose narrative-critical approaches because such a choice frees them from the rigors of historical analysis and exegesis. ${ }^{5}$

It bears mentioning that narrative criticism has been on the scene of NT scholarship for over three decades and has appeared in various iterations. ${ }^{6}$ It began its ascent in NT studies in the early 1980s in large part due to the frustration scholars felt at the state of Gospel scholarship mired in some of the less-than-helpful results of redaction-critical research. ${ }^{7}$ Literary approaches had first begun making inroads in Hebrew Bible scholarship in the late 1970s, and this was followed by two important works on the NT, one on the Gospel of Mark in 1982 and the other on the Gospel of John in $1983 .{ }^{8}$ During this period, Synoptic scholars working on

\footnotetext{
${ }^{5}$ If von Wahlde's ultimate concern is that those using narrative criticism have not done the same type of research in which he engages, then it is up to him to provide a more substantive critique than the one he has provided. Here he simply appears to reject the legitimacy of narrative criticism. One can also begin to detect von Wahlde's suspicion of the value of narrative criticism in his chapter "The Road Ahead: Three Aspects of Johannine Scholarship," in What We Have Heard from the Beginning: The Past, Present, and Future of Johannine Studies (ed. Tom Thatcher; Waco, TX: Baylor University Press, 2007) 345-49.

${ }^{6}$ See the fine overview provided by Michal Beth Dinkler, Literary Theory and the New Testament (AYBRL; New Haven: Yale University Press, 2019) 14-43.

${ }^{7}$ When the methodology was first introduced into NT studies, scholars referred to it as the "new criticism" or the "new literary criticism," terminology that arose out of literary-critical approaches to English literature where the major emphasis was a close reading of the text without explicit reference to the extratextual world. See Leroy Searle, "New Criticism," in The Johns Hopkins Guide to Literary Theory (ed. Michael Groden, Martin Kreiswirth, and Imre Szeman; Baltimore: Johns Hopkins University Press, 2005) 691-98.

${ }^{8}$ The first book-length work devoted to applying narrative criticism to one of the Gospels was
} 
redaction criticism (similar to what von Wahlde has termed "composition criticism" in his own work) offered seemingly endless proposals, each with its own starting point and each usually followed by a unique exposition of what constituted the various stages and phases of a given text's development. One of the besetting problems of such an approach - at least as it was being applied throughout the $1970 \mathrm{~s}$ - was that these proposals were often highly complex and tendentious, buoyed by a level of speculation that made them practically unfalsifiable. ${ }^{9}$ It is also important to note that there was little, if any, consensus among scholars employing redaction-critical methods about where to begin in a discussion of "the text." 10 All of this led to a genuine frustration among those who found redactional models helpful but wanted to apply the best insights of redaction criticism to the texts in their final forms. ${ }^{11}$ In particular, redaction criticism was especially useful for helping us understand that the Gospel writers were more than simply artless "compilers" (as envisioned by form criticism) but were sophisticated theologians in their own right. ${ }^{12}$ The difficulty was that even though redaction criticism had

the foundational book by David Rhoads and Donald Michie, Mark as Story: An Introduction to the Narrative of a Gospel (Minneapolis: Fortress, 1982); the book was released in a significantly revised and updated second edition in 1999 with Joanna Dewey, and again in a revised third edition in 2012. The second application of narrative criticism to the Gospels appeared the very next year with R. Alan Culpepper's volume, Anatomy of the Fourth Gospel: A Study in Literary Design (Minneapolis: Fortress, 1983). These were soon followed by Robert C. Tannehill, The Narrative Unity of LukeActs: A Literary Interpretation (2 vols.; Minneapolis: Fortress, 1986-89); and Jack Dean Kingsbury, Matthew as Story (Minneapolis: Augsburg Fortress, 1988).

${ }^{9}$ This same type of criticism has been leveled at von Wahlde's own highly complex theory of the development of the Johannine literature; see the following reviews: Wally V. Cirafesi (Journal of Greco-Roman Christianity and Judaism 8 [2011-12] 132-38); Richard I. Pervo (Sewanee Theological Review 55 [2012] 447-48); Brendan McConvery (ITQ 77 [2012] 200-202); Alicia Myers (RevExp 109 [2012] 308-9); Edward W. Klink III (JETS 55 [2012] 180-84).

${ }^{10}$ One of the most helpful critiques of the weaknesses of redaction criticism is C. Clifton Black, The Disciples according to Mark: Markan Redaction in Current Debate (JSNTSup 27; Sheffield: Sheffield Academic Press, 1989), which has now appeared in an updated second edition (Grand Rapids: Eerdmans, 2012) with a lengthy afterword in which Black reflects on the redactioncritical enterprise in the twenty-five years since his monograph was first published.

${ }^{11}$ For more on how these discussions evolved within the guild, see Christopher W. Skinner, "Telling the Story: The Appearance and Impact of Mark as Story," in Mark as Story: Retrospect and Prospect (ed. Kelly R. Iverson and Christopher W. Skinner; RBS 65; Atlanta: Society of Biblical Literature, 2011) 1-13.

${ }^{12}$ We can see the groundwork for this insight in the title of Willi Marxsen's formative work, Mark the Evangelist: Studies on the Redaction History of the Gospel (trans. James Boyce et al.; Nashville: Abingdon, 1979; original German: Der Evangelist Markus: Studien zur Redaktionsgeschichte des Evangeliums [FRLANT n.F 49; Göttingen: Vandenhoeck \& Ruprecht, 1956). To describe Mark as an "evangelist" meant that he exercised theological creativity in the formation of the final document. Such an insight stood against the well-known maxim that the Gospel writers should be understood as compilers of tradition; that view was explicitly stated by the great German form critic Martin Dibelius: "The literary understanding of the synoptics begins with the recognition that they are collections of material. The composers are only to the smallest extent authors. They are principally collectors, vehicles of tradition, editors" (From Tradition to Gospel [trans. B. L. 
generated this critical insight, practitioners of redaction criticism rarely, if ever, read the text from start to finish in a way that would help to show how the evangelists had generated unique theological portraits of Jesus. ${ }^{13}$ Regarding this trend, Patricia K. Tull comments:

Stories were studied as windows into the life situations reflected in the text. This approach not only built upon often shaky foundations but neglected claims made upon readers by the narratives themselves. Historical-critical discoveries were invaluable, but interpretation tended to mine, disassemble, and dispose of texts in pursuit of prior texts and circumstances that proved elusive and mostly irrecoverable. The final biblical texts, which for centuries before had been read as unities possessing theological meaning, were bypassed. Dissatisfaction with these weaknesses, coupled with interest in what close "New Critical" readings of scripture might reveal, led to new exegetical emphases. ${ }^{14}$

Thus, treating the NT narratives in their final forms was a way of allowing everyone to begin on the same page, both literally and figuratively. It was never meant, however, to provide a way out of dealing with thorny or perplexing historical questions.

One early fear expressed about NT narrative criticism was that it would devolve into a subjective ahistorical discipline concerned only with the world of the text itself, but, to be fair, few practitioners have gone this route. ${ }^{15}$ There is not space here to rehearse the history of narrative criticism's reception by scholars or

Woolf; Cambridge: James Clarke, 1971] 3; emphasis added; original German: Die Formgeschichte des Evangeliums [Tübingen: Mohr Siebeck, 1919]).

${ }^{13}$ Patricia K. Tull expresses this predicament well: "The quest for historical reconstruction similarly dominated biblical criticism. But while readers of recent literature could seek access to authorial biography, biblical interpreters were forced to reconstruct the historical milieu of passages through archaeology, epigraphy, and clues from the text itself. Using such historical tools, including source, form, and redaction criticism, scholars attempted to reconstruct the ancient world from which the texts emerged, including their assumed written and oral precursors. Meaning was sought not in the text's present form, but in a reconstructed event presumably underlying it" "Narrative Criticism and Narrative Hermeneutics," in The Oxford Encyclopedia of Biblical Interpretation [ed. Steven L. McKenzie; Oxford: Oxford University Press, 2013] 37-46, here 39).

${ }^{14}$ Ibid.

${ }^{15}$ For instance, in his review of Culpepper's Anatomy of the Fourth Gospel, D. A. Carson wrote, "If in some historical sense, we have been returned to our window -i.e., the narrator "reliably' tells us some things about Jesus' ministry; but if purely in the sense of the 'reliability' of the novelist, we have sacrificed the gospel's claims to certain historical specificity, and set sail on a shoreless sea of existential subjectivity. In that case the meaning may be in the story, the story that we perceive, the story that stands on our side of the text; but it tells us nothing of the ministry of Jesus on the other side" (D. A. Carson, review of Anatomy of the Fourth Gospel, by R. Alan Culpepper, Trinity Journal 4 [1983] 124; emphasis added). Similar critiques characterized some of the earliest reception of narrative criticism into a guild that was focused on tracing the layers and stages of John's composition. 
growth within Gospels research over the past three-and-a-half decades. ${ }^{16}$ It should be stated, however, that, while narrative criticism explicitly concerns itself with the texts of the Gospels in their final forms while also emphasizing unity in the text, most narrative critics with whom I have collaborated and whose scholarship I have engaged over the past two decades do not demonstrate by their work that such foci absolve them from wrestling with difficult textual or historical issues.

\section{Von Wahlde 's Sample Size}

The foregoing leads to a second criticism. In the second section of von Wahlde's article (223-29), he begins by critiquing specific narrative treatments of the religious leaders in John, setting his sights in particular on recent studies by Cornelis Bennema, Ruben Zimmermann, and Uta Poplutz. ${ }^{17}$ Given the sweeping claims that von Wahlde goes on to make about how narrative critics as a rule treat the religious authorities in John, one would hope for a truly representative sample. Instead, these three scholars serve as the basis for a lengthier exposition of von Wahlde's own views and appear to be evidence of confirmation bias. ${ }^{18}$ For example, after his very brief treatments of Bennema (225-26), Zimmermann (226-27), and

${ }^{16}$ Mark Allan Powell helpfully traces at least three iterations of narrative criticism that have been operative over the past three decades: (1) author-oriented narrative criticism, (2) readeroriented narrative criticism, and (3) text-oriented narrative criticism ("Narrative Criticism: The Emergence of a Prominent Reading Strategy," in Mark as Story: Retrospect and Prospect [ed. Iverson and Skinner], 19-43). Each approach has its own foci even though each is rooted in primary assumptions such as the overall unity of the text in its final form, the coherence an audience expects to find in its interaction with the text, and an understanding that the text involves a rhetorical communication between the implied author and implied audience.

${ }^{17}$ Cornelis Bennema, "The Identity and Composition of oi 'Tov反aio in the Gospel of John," TynBul 60 (2009) 239-63; Ruben Zimmermann, "The Jews': Unreliable Figures or Unreliable Narration?," in Character Studies in the Fourth Gospel (ed. Steven A. Hunt, D. Francois Tolmie, and Ruben Zimmermann; WUNT 314; Tubingen: Mohr Siebeck, 2013) 71-109; and Uta Poplutz, "The Pharisees: A House Divided," in Character Studies in the Fourth Gospel (ed. Hunt, Tolmie, and Zimmermann), 116-26.

${ }^{18}$ It is curious that von Wahlde criticizes Bennema for being too specific about the identity of of 'Tov\&aiol (226) and then immediately critiques Zimmermann for his conclusion that lacks specificity (226-27). Von Wahlde concludes, "To the benefit of scholarship, it would seem that Zimmermann's study reveals precisely why the current application of narrative criticism to the Gospel's characters is flawed" (227). If von Wahlde's point is that narrative criticism fails to yield consensus positions about one of the most notoriously difficult issues in interpreting the Fourth Gospel, then an appropriate reply would be that his standard is too high. Discussing the identity of the "Jews" in the Fourth Gospel has proven to be one of the most notoriously difficult pursuits in the history of Gospel interpretation. See the recent fruitful discussions in the Marginalia Forum: "Jew and Judean: A Forum on Politics and Historiography in the Translation of Ancient Texts" (https://marginalia.lareviewofbooks.org/jew-judean-forum/). This enlightening conversation includes Adele Reinhartz, Steve Mason, Daniel Schwartz, Annette Yoshiko Reed, Joan Taylor, Malcolm Lowe, Jonathan Klawans, Ruth Sheridan, and James Crossley. 
Poplutz (227-29), von Wahlde writes: "Narrative criticism does not ask about the genesis of the text or the process of composition and so regularly decides, as a methodological procedure, to treat all instances of the term [Ioudaios] as having the same meaning" (229; emphasis added). He later concludes, "As we have seen from our review of recent narratological studies, it has been common for these scholars to attempt to treat the two sets of terms as a 'group character.' It has also been common for them to start from the conviction that the term 'Jews' has only one meaning in the Gospel" (241). At this juncture it would be appropriate to point out that von Wahlde has arrived as this broad and unqualified judgment after examining only three examples - two of which appear in the same volume ${ }^{19}$ while ignoring the vast amount of narrative-critical research undertaken over the past three decades in general, and the substantial number of character studies that have appeared in the last twenty years in particular. ${ }^{20}$ In short, the works he cites

${ }^{19}$ The chapters written by Zimmermann and Poplutz both appear in the same volume, Character Studies in the Fourth Gospel. As a contributor to that volume, I can speak directly to the editorial instructions provided to us. Contributors were informed that the first chapter of the volume would consist of a lengthy discussion of the history and methodological development of character studies in recent NT research, and we were thus asked to limit the discussion of any specific methodological concerns in our essays and proceed to analyzing the character or character groups assigned. This means that two of von Wahlde's three conversation partners contain a limited exposition of a specific methodological framework and perhaps make his facile critique even easier.

${ }^{20}$ Since 1997, nearly two dozen monographs have appeared specifically devoted to issues in Johannine characterization, many of which have discussions of oi 'Tovfoĩol. Curiously, von Wahlde cites several of these (223-24 n. 2) but never interacts with them in his critique of "recent studies." See in chronological order of publication, David R. Beck, The Discipleship Paradigm: Readers and Anonymous Characters in the Fourth Gospel (BIS 27; Leiden: Brill, 1997); Adeline Fehribach, The Women in the Life of the Bridegroom: A Feminist Historical-Literary Analysis of the Female Characters in the Fourth Gospel (Collegeville, MN: Liturgical Press, 1998); Colleen M. Conway, Men and Women in the Fourth Gospel: Gender and Johannine Characterization (SBLDS 167; Atlanta: Society of Biblical Literature, 1999); Tobias Nicklas, Ablösung und Verstrickung: "Juden" und Jüngergestalten als Charaktere der erzählten Welt des Johannesevangeliums und ihre Wirkung auf den impliziten Leser (RST 60; Frankurt am Main: Lang, 2001); Peter Dschulnigg, Jesus begegnen: Personen und ihre Bedeutung im Johannesevangelium (Theologie 30; Munster: LIT, 2002); Stan Harstine, Moses as a Character in the Fourth Gospel: A Study of Ancient Reading Techniques (JSNTSup 229; Sheffield: Sheffield Academic Press, 2002); Susanne Ruschmann, Maria von Magdala: Jüngerin, Apostolin, Glaubensvorbild (Stuttgart: Katholisches Bibelwerk, 2003); Margaret M. Beirne, Women and Men in the Fourth Gospel: A Genuine Discipleship of Equals (JSNTSup 242; Sheffield: Sheffield Academic Press, 2003); Philip F. Esler and Ronald A. Piper, Lazarus, Mary and Martha: A Social-Scientific and Theological Reading of John (London: SCM, 2006); Judith Hartenstein, Charakterisierung im Dialog: Die Darstellung von Maria Magdalena, Petrus, Thomas und der Mutter Jesu im Kontext anderer früchristlicher Traditionen (NTOA 64; Gottingen: Vandenhoeck \& Ruprecht, 2007); Bradford B. Blaine Jr., Peter in the Gospel of John: The Making of an Authentic Disciple (AcBib 27; Atlanta: Society of Biblical Literature, 2007); Christopher W. Skinner, John and Thomas: Gospels in Conflict? Johannine Characterization and the Thomas Question (PTMS 115; Eugene, OR: Pickwick, 2009); Susan Hylen, Imperfect Believers: Ambiguous Characters in the Gospel of John (Louisville: Westminster John Knox, 2009); Cornelis Bennema, Encountering Jesus: Character Studies in the Gospel of John (Minneapolis: Fortress, 
are neither representative of the whole of narrative criticism nor even of the authors cited. ${ }^{21}$

Further, one might respond to von Wahlde's claim about narrative criticism's disinterest in issues of composition by affirming that, while narrative criticism alone does not concern itself with issues of composition or the genesis of the Gospel, those who employ narrative criticism have consistently concerned themselves with these questions. Many if not most scholars who use narratological approaches for exegetical purposes do so explicitly in concert with other methods. In Johannine circles, one could identify the work of scholars such as Adele Reinhartz, Andrew T. Lincoln, and Francis J. Moloney, all of whom have produced important works on the Fourth Gospel from narrative perspectives and all of whom discuss such historical and compositional issues at length. ${ }^{22}$

In a recent chapter that reads like an intellectual biography, Moloney details how historical concerns have anchored his literary approach throughout his prolific writing career, beginning just after his doctoral research at Oxford University. ${ }^{23}$ In a section entitled "Narrative Is Not Enough," Moloney writes:

Contemporary narrative approaches to these ancient and canonical texts have to situate themselves more critically within the scholarly disciplines developed by the his-

2009); Nicolas Farrelly, The Disciples in the Fourth Gospel: A Narrative Analysis of Their Faith and Understanding (WUNT 2/290; Tübingen: Mohr Siebeck, 2010); Michael W. Martin, Judas and the Rhetoric of Comparison in the Fourth Gospel (New Testament Monographs 25; Sheffield: Sheffield Phoenix Press, 2010); Alicia Myers, Characterizing Jesus: A Rhetorical Analysis of the Fourth Gospel's Use of Scripture in Its Presentation of Jesus (LNTS 458; London: Bloomsbury T\&T Clark, 2012); Christopher W. Skinner, ed., Characters and Characterization in the Gospel of John (LNTS 461; London: Bloomsbury T\&T Clark, 2013); Hunt, Tolmie, and Zimmermann, Character Studies in the Fourth Gospel (2013).

${ }^{21}$ For example, Cornelis Bennema has written an entire monograph dedicated to developing an overarching understanding of characterization in the NT (A Theory of Character in New Testament Narrative [Minneapolis: Fortress, 2014]). A fuller exposition of Poplutz's narratological approach, can be found in her monograph Erzählte Welt: Narratologische Studien zum Matthäusevangelium (Biblisch-theologische Studien 100; Göttingen: Vandenhoeck \& Ruprecht, 2008). Ruben Zimmermann has written extensively on hermeneutics and critical methodology, especially as it relates to narrative approaches. For one related example, see "The Narrative Hermeneutics in John 11: Learning with Lazarus How to Understand Death, Life, and Resurrection," in The Resurrection of Jesus in the Gospel of John (ed. Craig R. Koester and Reimund Beiringer; WUNT 222; Tübingen: Mohr Siebeck, 2008) 75-102.

${ }^{22}$ See Adele Reinhartz, Befriending the Beloved Disciple: A Jewish Reading of the Gospel of John (London: Continuum, 2002); see also her more generally focused monograph "Why Ask My Name?" Anonymity and Identity in Biblical Narrative (Oxford: Oxford University Press, 1998); Francis J. Moloney, Belief in the Word: Reading John 1-4 (Minneapolis: Fortress, 1993); idem, Signs and Shadows: Reading John 5-12 (Minneapolis: Fortress, 1996); idem, Glory Not Dishonor: Reading John 13-21 (Minneapolis: Fortress, 1998); idem, The Gospel of John: A Commentary (SacPag 4; Collegeville, MN: Liturgical Press, 1998); Andrew T. Lincoln, The Gospel according to Saint John (BNTC 4; Peabody, MA: Hendrickson, 2005).

${ }^{23}$ Francis J. Moloney, "From History, into Narrative, and Beyond," in his Johannine Studies: 1975-2017 (WUNT 372; Tübingen: Mohr Siebeck, 2017) 1-29. 
torical critical period, especially form criticism and redaction criticism: What gave birth to the Johannine story? What are the cultural influences that one can find within it? Is it Jewish, Greek? Is it Christian, Gnostic? How are we to explain the Aporien that are present in the text as we have it? Do they reflect the juxtaposing of traditions from various stages in the development of the narrative? If such is the case: who and what is responsible for the various stages that one might trace within the narrative as we now have it? Old questions that have never been definitively resolved must continue to be asked. ${ }^{24}$

More important for the present considerations, Moloney explicitly acknowledges the following just a little further down the same page: "We cannot merely sidestep the consistently negative use of the expression of 'Tov $\delta$ aĩo as some sort of literary device to the point where we do not ask how, when, and why this expression assumed its role in the narrative. In other words, it is dishonest scholarship to interpret an ancient and (for some) a normative text, without asking historical questions." 25 This is one recent example of a narrative approach that embraces the complexities that von Wahlde seems to think narrative critics avoid.

In my own recent discussion of Judaism and the role of "the Jews" in John 9 , I have written the following:

[E]ven though the gospel presents a sharp conflict between Jesus and the Jewish leaders, such a conflict is historically unlikely. The Jesus movement was likely not big enough during Jesus' lifetime for such a significant divide to have developed. In addition the strict dualism between Jesus on one end and "the Jews" on the other supports the gospel's dualistic emphasis and fails to account for the rich diversity that existed within Judaism in the first century. Instead, these elements of the narrative likely derive from the third stage of the gospel's development. . . . Practically, this means that when hoi Ioudaioi is used negatively, the phrase is functioning as a technical term for the enemies of Jesus in the narrative rather than a historical or strictly ethnic designation. The phrase is more a reflection of the conflicts that arose during the time in which the gospel was written rather than something that took place during Jesus' historical context in the late $20 \mathrm{~s} \mathrm{CE} .{ }^{26}$

This excerpt explicitly addresses historical and literary concerns, while also paying attention to concerns about the stages of the text's composition. Further, the excerpt is also trying to be as careful as possible with the evidence regarding of 'Iov $\delta a$ ĩor and the religious leaders across the Fourth Gospel. Von Wahlde is free to disagree with my conclusions, or with those offered by Moloney, Lincoln, Reinhartz, or the host of other Johannine scholars employing narratological approaches, but he should not simply dismiss these attempts as having completely neglected all of the "complexities and perplexities" of the text.

${ }^{24}$ Ibid., 11 (emphasis added).

${ }^{25}$ Ibid., 12 (emphasis added).

${ }^{26}$ ChristopherW. Skinner, Reading John (Cascade Companions; Eugene, OR: Cascade, 2015) 53 (emphasis added). 


\section{Von Wahlde's Reception of the Text}

In the third section of his article (230-41), von Wahlde transitions from his critique of narrative-critical readings to a fuller exposition of his own views. He sees at least two different groups represented by the various terms used to designate

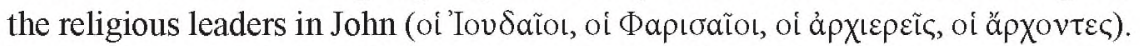
First, according to von Wahlde, the term'Iov $\delta a i$ o has three meanings in the Gospel —one is a reference to "Judeans," one is a reference to national and ethnic identity, and one is a reference to the religious leaders. Second, the specific terms used to designate the religious leaders in John are never to be conflated with the term 'Iov\&aĩol. These groups represent two different plot lines and two different settings in the narrative. He concludes, "On the basis of the study of the group character of the religious authorities, it is clear that there are two groups of authorities and they each have a different role in the narrative. In addition, the differences are not just stylistic, they also manifest differences of theology" (243). As indicated above, von Wahlde's proposal is rooted in his broader approach to the Johannine literature, which sees three different versions of the text standing behind the Fourth Gospel in its final form. He sees each title reflecting a different version of the Gospel with its own distinct christology, and each being incorporated not so seamlessly into the wider composition.

After an unveiling of von Wahlde's critique alongside his proposal for understanding the various terms for the Jewish leaders in John, there remains a glaring lacuna in his discussion: How would an ancient audience—real or implied-experience the text as von Wahlde envisions it? Simply stated, the composition theory he advances, as sophisticated as it is, does not address and cannot ultimately account for how earliest audiences could have navigated their experience with this text. Let us grant, for the sake of argument, that von Wahlde is correct in his assertions that there are different meanings for the various terms used to refer to the religious leaders in John and that these meanings constitute untidy seams in the final text. Is it reasonable to think that an early audience of the Fourth Gospel could have received the text in a way that accentuates these different definitions and so reinforces the disunity von Wahlde emphasizes? To state it another way, even if we can agree on the disunity von Wahlde sees in the text, are we able to fit his conclusions into a reading of the narrative that would have made sense in a first-century context? It is difficult to envision a scenario that would allow us to answer in the affirmative.

\section{Reading John 9:1-10:21: A Test Case}

It is possible to illustrate some of the difficulties raised by an application of von Wahlde's method by briefly examining the movement of various terms used for the Jewish religious leaders across John 9:1-10:21. The unit begins with Jesus 
healing a man born blind ( $9: 1-12)$. In v. 13, the man is brought before the Pharisees, who begin questioning him. The Pharisees are again mentioned in vv. 15 and 16 ,

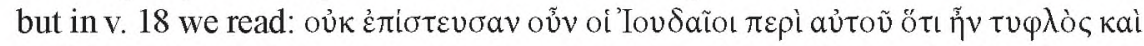

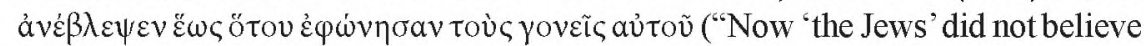
that he had been blind and had received his sight until they summoned his parents"

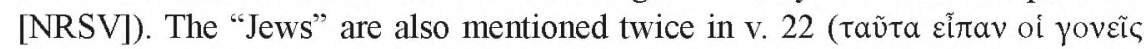
$\alpha$ ủ

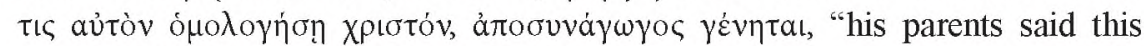
because they feared the Jews; for the Jews had already agreed that anyone who confessed him to be the Messiah would be put out of the synagogue" [NRSV]).

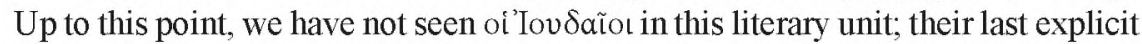
appearance was in 8:57, but there are several strong indications that 9:1 represents a new temporal and spatial setting for Jesus and the disciples. ${ }^{27}$ This means that an audience is more likely to associate these "Jews" with the "Pharisees" who have just been questioning Jesus in vv. 13-16.

By the time we get to vv. 24-34, a more pressing question is, Who exactly are the antagonists? Neither "Pharisees" nor "Jews" are explicitly named though both have recently been in the foreground. Instead, the group at odds with Jesus across this section is simply referred to as "they." The generic "they" is indicated by the

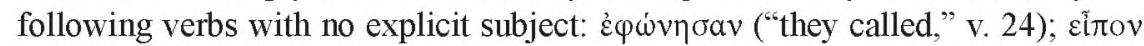

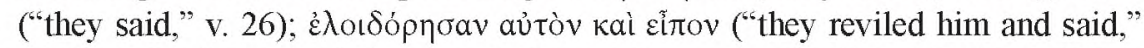

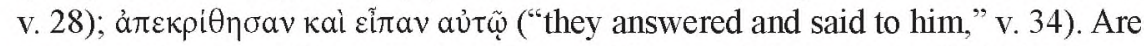
these interlocutors "Pharisees" or "Jews"? If we read through von Wahlde's lens, we would have to choose one over the other. But, given the way the narrative is constructed, is it really necessary for an audience to choose between "Pharisees" and "Jews" here? A generic audience, assuming unity and coherence, would likely equate the two. Further, given the literary unity across 9:1-10:21, which nearly every commentator recognizes, how do we explain the return of the Pharisees in 9:40? And, an even more perplexing question: Using von Wahlde's model, how do we explain that the Good Shepherd material that follows in 10:1-18

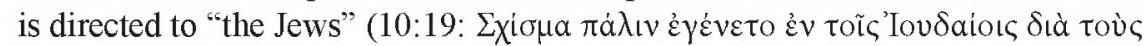
$\lambda$ óyous toútous, "Again there was division among the Jews on account of these words" [NRSV]) but flows directly from the material in 9:39, where there is no explicit subject? An acceptable reading of the text would, at the very least, allow for an audience to conflate the two in this literary unit. Of course, von Wahlde may be correct that this overall unit is a composition pieced together from a variety of sources. But it is also widely accepted that this passage is a masterful narrative that subtly and indiscriminately associates "the Pharisees" and "the Jews." Both claims

${ }^{27}$ In 8:59, Jesus hides himself from those who are trying to stone him and departs from the

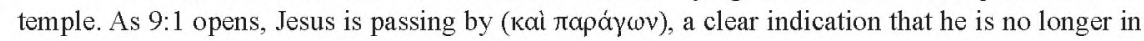
the area of the temple. 
have the right to detailed examination-von Wahlde's emphasis on the prehistory and sources of the text, and the emphasis on the narrative's reception in its final form.

Audiences, both ancient and modern, inherently work from the assumption that the texts they experience have both unity and coherence. This is a simple fact of human encounters with written and spoken texts, narrative or otherwise. Thus, when narrative critics approach a text, they are attempting to account for how that text-which may or may not have layers of composition—came to be regarded as a unified and coherent whole in its final form. Simply stated, someone at some point valued the final version of the Fourth Gospel as a unified and coherent text. Von Wahlde's approach heavily emphasizes disunity, and so fails to account, both historically and literarily, for how a first-century reader/hearer would have been able to encounter such diversity without automatically making an interpretive move toward some sort of internal unity. Here is where I believe the differences in our respective methodologies become clearest, and this could ultimately be a potential basis for talking past one another, something I am eager to avoid in the present article.

\section{Conclusion}

In closing, I offer the following remarks:

1. Not all research does or must do the same things. Prof. von Wahlde has fruitfully involved himself for over three decades in composition criticism on the Johannine literature, and his research has been consistently hailed as worthy of careful consideration. It is a fair criticism to say that his focus on the areas of disunity in the Fourth Gospel's composition leads him to place emphasis on certain concerns, while narrative critics - with their concomitant emphasis on unity in the text-focus on other concerns. It is possible for two very different methodologies to coexist peacefully and to inform one another meaningfully. Narrative criticism does something, but it does not do everything. The same can be said for von Wahlde's composition-critical approach. Both approaches have their benefits, and both have their limitations. It behooves us all to be honest about what those benefits and limitations are. In another of his publications, von Wahlde notes, "As a result of my years of teaching, I am convinced that students (from undergraduate to doctoral) tend to see what they are taught to see." 28 While there is much truth to this assertion, it is also true that all of us, to a certain degree, see what we want to see. No student of these texts is methodologically or ideologically disinterested, and we must be honest about that as well.

${ }^{28}$ Von Wahlde, "Road Ahead," 348. 
2. There is a central and incontrovertible fact with which we must wrestle in Gospels research that is overlooked in von Wahlde's treatment of narrative criticism: The Gospels as we now have them reached their final forms at a given point in time for specific reasons. One of these reasons was surely that they were regarded as valuable and authoritative within early communities in those forms. It is possible to wrestle, on one side, with all of the questions that surround the composition of these texts and still concern ourselves with treating the texts as coherent and autonomous wholes. ${ }^{29}$ It seems clear that the earliest reception of these texts gave priority to the latter rather than the former approach. ${ }^{30}$ In other words, it takes a fair bit of imagination to suggest that ancient audiences approached or even could have approached the text with the sort of disunity hermeneutic von Wahlde constructs. Narratives that stand the test of time, by definition, have an assumed unity and coherence; audience expectations go hand in hand with genre conventions.

3. It is my hope that this article will prove useful for future conversations in which those with differing methodologies seek first to understand those whom they critique rather than dismissing them. This applies not only to von Wahlde and me, but to those in the guild who are quick to dismiss as "dead ends" what others might be doing with fruitful results. ${ }^{31}$ Newer methodologies can and should be criticized, but not simply because they are new. ${ }^{32}$ What needs to be demonstrated from those who offer such critiques is that such methodologies have no ability to answer old questions or raise new ones. To the contrary, this article has attempted to demonstrate that narrative criticism can do both, and thus it should not be so easily dismissed.

${ }^{29}$ In one of his foundational articles, Wayne Meeks demonstrates his awareness of the value of holding these two ideas in a necessary tension: "The major literary problem of John is its combination of remarkable stylistic unity and thematic coherence with glaringly bad transitions between episodes at many points. The countless displacement, source, and redaction theories that litter the graveyards of Johannine research are voluble testimony to this difficulty. ... On the other hand, not all the aporiae in the present form of the gospel can be attributed to clumsy redaction; most of them evidently were acceptable to the evangelist, despite his ability to produce large, impressively unified literary compositions (the trial and crucifixion scenario, as the most notable example). There are a number of examples not only of double entendre which are progressively clarified by repetition and modification, but also of self-contradiction that are manifestly deliberate" ("The Man from Heaven in Johannine Sectarianism," JBL 91 [1972] 44-72, here 48.)

${ }^{30}$ Even a cursory glance at earliest patristic readings of the Fourth Gospel demonstrates that the default assumption was to understand the text as a unity with theological meaning.

${ }^{31}$ See, e.g., Paul Foster, "Memory, Orality, and the Fourth Gospel: Three Dead-Ends in Historical Jesus Research," Journal for the Study of the Historical Jesus 10 (2012) 191-227; Larry W. Hurtado, "Oral Fixation and New Testament Studies? 'Orality,' 'Performance' and Reading Texts in Early Christianity," NTS 60 (2014) 321-40.

${ }^{32}$ Given their ubiquity within contemporary scholarship over several decades, it feels strange to refer to narratological approaches as "newer methods," but in the context of this article it seems appropriate in view of Prof. von Wahlde's dismissal. 